Article

\title{
Two New Flavonoids from the Leaves of Baccharis oblongifolia (Ruiz and Pav.) Pers. (Asteraceae)
}

\author{
Paulo R. F. Zampieri ${ }^{1}$, Cinthia I. Tamayose ${ }^{1}$, Oriana A. Fávero ${ }^{2}$, Paulete Romoff ${ }^{2}$ and \\ Marcelo J. P. Ferreira 1,*(D) \\ 1 Departamento de Botânica, Instituto de Biociências, Universidade de São Paulo, São Paulo 05508-090, Brazil \\ 2 Universidade Presbiteriana Mackenzie, São Paulo CEP 01302-907, Brazil \\ * Correspondence: marcelopena@ib.usp.br; Tel.: +55-11-3091-7546
}

Received: 8 August 2019; Accepted: 30 August 2019; Published: 3 September 2019

check for updates

\begin{abstract}
In this work, two new flavonoids, oblongifolioside A (1) and oblongifolioside B (2), along with eight known compounds (3-10), are isolated from the leaves of Baccharis oblongifolia (Asteraceae). The new structures are established through spectroscopic data and the known compounds are identified by comparison with data reported in the literature. The compounds (1-10) are evaluated in relation to their antiradical properties. Compounds $\mathbf{1}$ and $\mathbf{2}$ are found to exhibit high antiradical activity compared to their respective non-acylated flavonoids.
\end{abstract}

Keywords: Baccharis; Astereae; Compositae; flavonoids; chlorogenic acid derivatives; antiradical properties

\section{Introduction}

Baccharis L. (Astereae, Asteraceae) is a large New World genus comprising between 354 and 500 species [1,2]. Approximately $90 \%$ of Baccharis species are found in South America and distributed mainly in the warm temperate and tropical regions of Argentina, Brazil, Chile, Colombia, and Mexico. In Brazil, 179 species are found chiefly in the Southern and Southeastern regions. Among them, 115 are endemic species [3] which are restricted to the elevated altitudes of the Atlantic Forest.

Some Baccharis species are used in folk medicine, including for spasmolytic, diuretic, and analgesic purposes and for the treatment of ulcers, fever, gastrointestinal illnesses, diabetes, and microbial infections [4-6]. Previous phytochemical studies of this genus have reported several classes of natural products, such as chlorogenic acid derivatives [4,7-10], terpenoids [11-22], especially diterpenes with dozens of isolated compounds from Baccharis [4,5,17-22], and flavonoids from flavone, flavanone, and flavonol types [4,5,21-26]. Furthermore, it has also been described as having diverse biological activities including antimicrobial [4-6,14,15], antiviral [4-6], antiprotozoal [9,24,25], anti-inflammatory $[10,13]$, cytotoxic $[4-6,23]$, and antioxidant $[7,13-15,22,23]$, as well as antimutagenic and chemopreventive effects [4-6].

In our continuing efforts in the search for new bioactive compounds from Brazilian Asteraceae species, this paper describes two new acylated flavonoids, oblongifolioside A (1) and oblongifolioside B (2), and eight known compounds (3-10) from B. oblongifolia leaves, as shown in Figure 1. The new structures were elucidated by spectroscopic data and the known ones were identified by comparison with literature data. Herein, we report the isolation, structure elucidation, and antiradical activities of these compounds. 


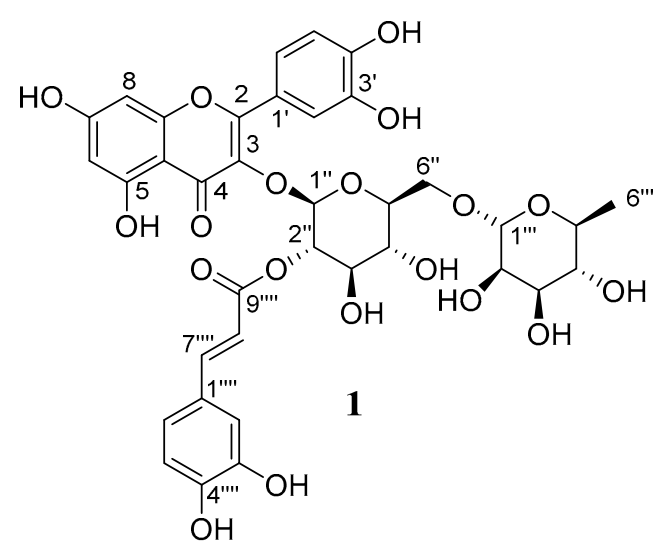<smiles>O=C(O)/C=C/c1ccc(O)c(O)c1</smiles><smiles>C[C@H]1O[C@H](OC[C@H]2O[C@H](Oc3c(-c4ccc(O)c(O)c4)oc4cc(O)cc(O)c4c3=O)[C@H](O)[C@H](O)[C@H]2O)[C@H](O)[C@@H](O)[C@@H]1O</smiles>

5<smiles>C[C@@H]1O[C@H](OC[C@H]2O[C@@H](Oc3c(-c4ccc(O)cc4)oc4cc(O)cc(O)c4c3=O)[C@H](OC(=O)/C=C/c3ccc(O)c(O)c3)[C@@H](O)[C@H]2O)[C@H](O)[C@@H](O)[C@@H]1O</smiles><smiles>O=C(/C=C/c1ccc(O)c(O)c1)O[C@H]1C[C@@](O)(C(=O)O)C[C@H](O)[C@H]1O</smiles><smiles>C[C@@H]1O[C@H](OC[C@H]2O[C@@H](Oc3c(-c4ccc(O)cc4)oc4cc(O)cc(O)c4c3=O)[C@H](O)[C@H](O)[C@H]2O)[C@H](O)[C@H](O)[C@@H]1O</smiles>

6<smiles>O=C(/C=C/c1ccc(O)c(O)c1)O[C@H]1C[C@@](O)(C(=O)O)C[C@H](O)[C@H]1OC(=O)/C=C/c1ccc(O)c(O)c1</smiles><smiles>O=C(/C=C/c1ccc(O)c(O)c1)O[C@H]1C[C@](O)(C(=O)O)C[C@H](OC(=O)/C=C/c2ccc(O)c(O)c2)[C@@H]1OC(=O)/C=C/c1ccc(O)c(O)c1</smiles>

Figure 1. Compounds identified from B. oblongifolia leaves.

\section{Results}

\section{Structural Elucidation}

Oblongifolioside A (1) was isolated as a yellow powder. The molecular formula of $\mathbf{1}$ was assigned $\mathrm{C}_{36} \mathrm{H}_{36} \mathrm{O}_{19}$ based on its HRESIMS at $m / z 771.1772[\mathrm{M}-\mathrm{H}]^{-}$, indicating 19 degrees of unsaturation. The 
UV spectrum exhibited absorption maxima at 254 and $345 \mathrm{~nm}$, with a shoulder at $315 \mathrm{~nm}$. The ${ }^{1} \mathrm{H}$ NMR spectrum showed four doublets at $\delta 6.29(1 \mathrm{H}, J=2.0 \mathrm{~Hz}, \mathrm{H}-6)$ and $\delta 6.13(1 \mathrm{H}, J=2.0 \mathrm{~Hz}, \mathrm{H}-8)$ referring to the meta-coupling of H-6 and H-8 hydrogens from an A-ring of flavonoids, and $\delta 7.57(1 \mathrm{H}, J=2.1 \mathrm{~Hz}$, $\left.\mathrm{H}-2^{\prime}\right), \delta 6.86\left(1 \mathrm{H}, J=8.1 \mathrm{~Hz}, \mathrm{H}-5^{\prime}\right)$ and a doublet of doublets at $\delta 7.56(1 \mathrm{H}, J=2.1 \mathrm{~Hz}$ and $8.1 \mathrm{~Hz})$ attributed to a $1^{\prime}, 3^{\prime}, 4^{\prime}$-trisubstituted B-ring of flavonoids. A quercetin derivative was suggested by the absence of additional signals pertaining to hydrogen at $\mathrm{H}-3$ as well as methoxyl groups. The aromatic region also showed two other doublets at $7.62\left(1 \mathrm{H}, J=15.8 \mathrm{~Hz}, \mathrm{H}-7^{\prime \prime \prime \prime}\right)$ and $\delta 6.33(1 \mathrm{H}, J=15.8 \mathrm{~Hz}$, $\left.\mathrm{H}-8^{\prime \prime \prime \prime}\right)$ assigned to trans-hydrogens from an $\alpha, \beta$-unsaturated carboxyl group, two doublets at $\delta 7.06$ $\left(1 \mathrm{H}, J=2.1 \mathrm{~Hz}, \mathrm{H}-2^{\prime \prime \prime \prime}\right)$ and $\delta 6.78\left(1 \mathrm{H}, J=8.2 \mathrm{~Hz}, \mathrm{H}-5^{\prime \prime \prime \prime}\right)$ corresponding to meta- and ortho-couplings between hydrogens, respectively, and a doublet of doublets at $\delta 6.94\left(1 \mathrm{H}, J=2.1 \mathrm{~Hz}\right.$ and $\left.8.2 \mathrm{~Hz}, \mathrm{H}-6^{\prime \prime \prime \prime}\right)$. These data allowed for the verification of the presence of a caffeoyl group in the structure. Additionally, the ${ }^{1} \mathrm{H}$ NMR spectrum showed a doublet at $\delta 5.48\left(1 \mathrm{H}, J=8.0 \mathrm{~Hz}, \mathrm{H}-1^{\prime \prime}\right)$ and a broad singlet at $\delta$ $4.55\left(1 \mathrm{H}, \mathrm{H}-1^{\prime \prime \prime}\right)$, which is characteristic of hydrogens bonded in anomeric carbons. Three additional doublets at $3.87\left(1 \mathrm{H}, J=9.5 \mathrm{~Hz}, \mathrm{H}-6^{\prime \prime}\right), \delta 3.27\left(1 \mathrm{H}, J=9.5 \mathrm{~Hz}, \mathrm{H}-6^{\prime \prime}\right)$ and $\delta 1.13\left(3 \mathrm{H}, J=6.2 \mathrm{~Hz}, \mathrm{H}-6^{\prime \prime \prime}\right)$ suggested the presence of a glycosyl moiety substituted at C- $6^{\prime \prime}$ and a rhamnosyl unit in the structure. The doublet of doublets at $\delta 5.04\left(1 \mathrm{H}, J=8.0 \mathrm{~Hz}\right.$ and $\left.9.6 \mathrm{~Hz}, \mathrm{H}-2^{\prime \prime}\right)$ suggested the presence of a substituent group at C-2" from the glycosyl moiety (Figures S1 and S2).

The ${ }^{13} \mathrm{C}$ NMR spectrum displayed thirty-six carbon signals, including a carbonyl, a carboxyl, twelve quaternary carbons, ten unsaturated methines, ten oxymethines, one oxygenated methylene, and one methyl group. Through HMBC correlations, it was possible to establish the connectivity among groups in the structure. The signals at $\delta 5.48$ and $\delta 5.04$ attributed to $\mathrm{H}-\mathrm{1}^{\prime \prime}$ and $\mathrm{H}-2^{\prime \prime}$ from the glycosyl moiety correlated with the carbons at $\delta 133.3$ and $\delta 167.2$, respectively, which were attributed to C-3 from quercetin and to C-9'"' from a caffeoyl group. These correlations confirmed the glucose at $\mathrm{C}-3$ of quercetin and the caffeoyl group esterified on hydroxyl at C-2" of glucose. Other key HMBC correlations are shown in Figure 2. With the aid of HSQC and HMBC experiments, all ${ }^{1} \mathrm{H}$ and ${ }^{13} \mathrm{C}$ NMR signals of 1 were assigned as shown in Table 1 (Figure S3-S5).

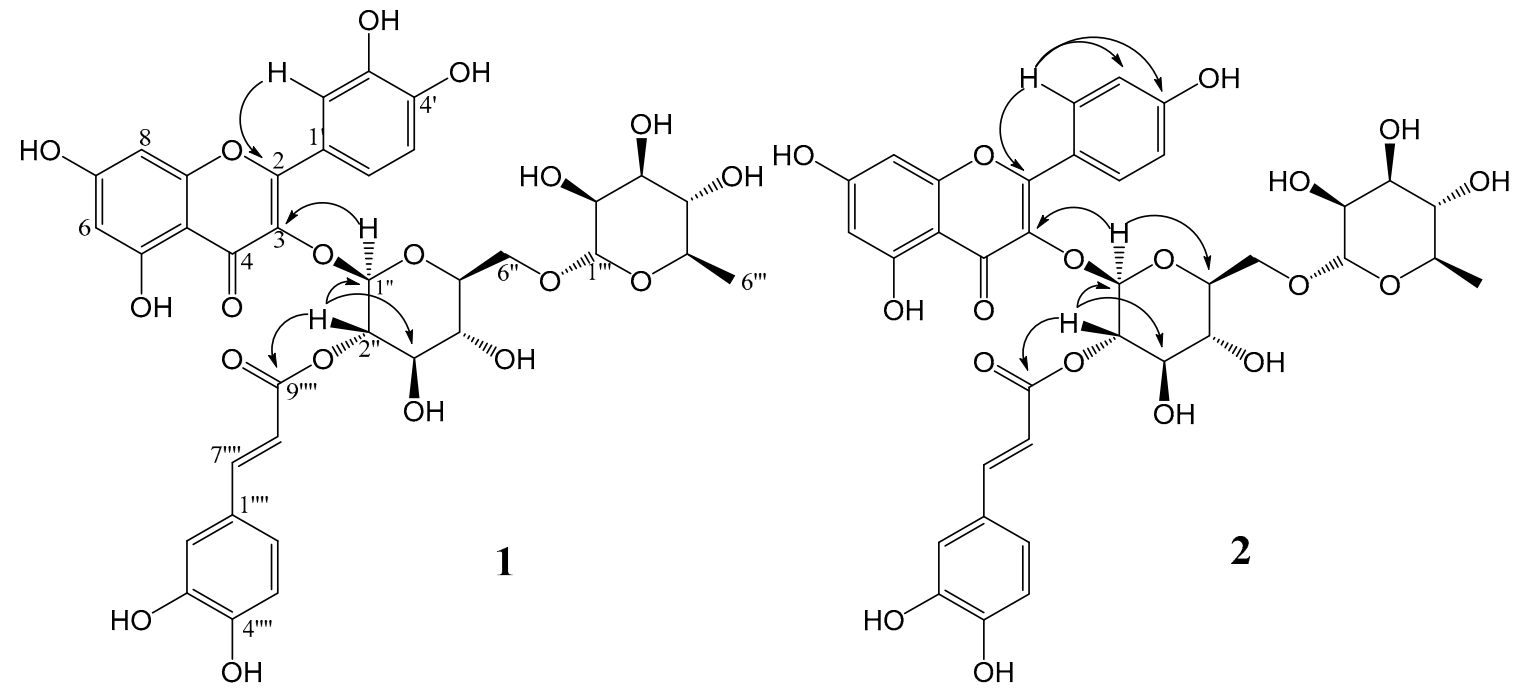

Figure 2. Key HMBC correlations of compounds 1 and 2.

Oblongifolioside B (2) was isolated as a yellow powder. The molecular formula of 2 was assigned as $\mathrm{C}_{36} \mathrm{H}_{36} \mathrm{O}_{18}$ based on its HRESIMS at $\mathrm{m} / \mathrm{z} 755.1881[\mathrm{M}-\mathrm{H}]^{-}$, indicating 19 degrees of unsaturation. The UV spectrum exhibited absorption maxima at 260 and $330 \mathrm{~nm}$, with a shoulder at $300 \mathrm{~nm}$. The ${ }^{1} \mathrm{H}$ NMR spectrum showed two doublets at $\delta 7.99\left(2 \mathrm{H}, J=8.4 \mathrm{~Hz}, \mathrm{H}-2^{\prime}, 6^{\prime}\right)$ and $\delta 6.90$ $\left(2 \mathrm{H}, J=8.4 \mathrm{~Hz}, \mathrm{H}-3^{\prime}, 5^{\prime}\right)$ attributed to ortho-coupling of hydrogens from a para-substituted B-ring of flavonoids. Two broad singlets were observed at $\delta 6.35(1 \mathrm{H}, \mathrm{H}-8)$ and $\delta 6.17(1 \mathrm{H}, \mathrm{H}-6)$ assigned to 
hydrogens from an A-ring of flavonoids. A kaempferol derivative was suggested by the absence of additional signals pertaining to hydrogen at H-3 as well as methoxyl groups (Figure S6-S11).

Table 1. ${ }^{1} \mathrm{H},{ }^{13} \mathrm{C}$ and $\mathrm{HMBC}$ NMR data of 1 and 2 ( $\delta$ in ppm, $J$ in $\mathrm{Hz}, \mathrm{CD}_{3} \mathrm{OD}$ ).

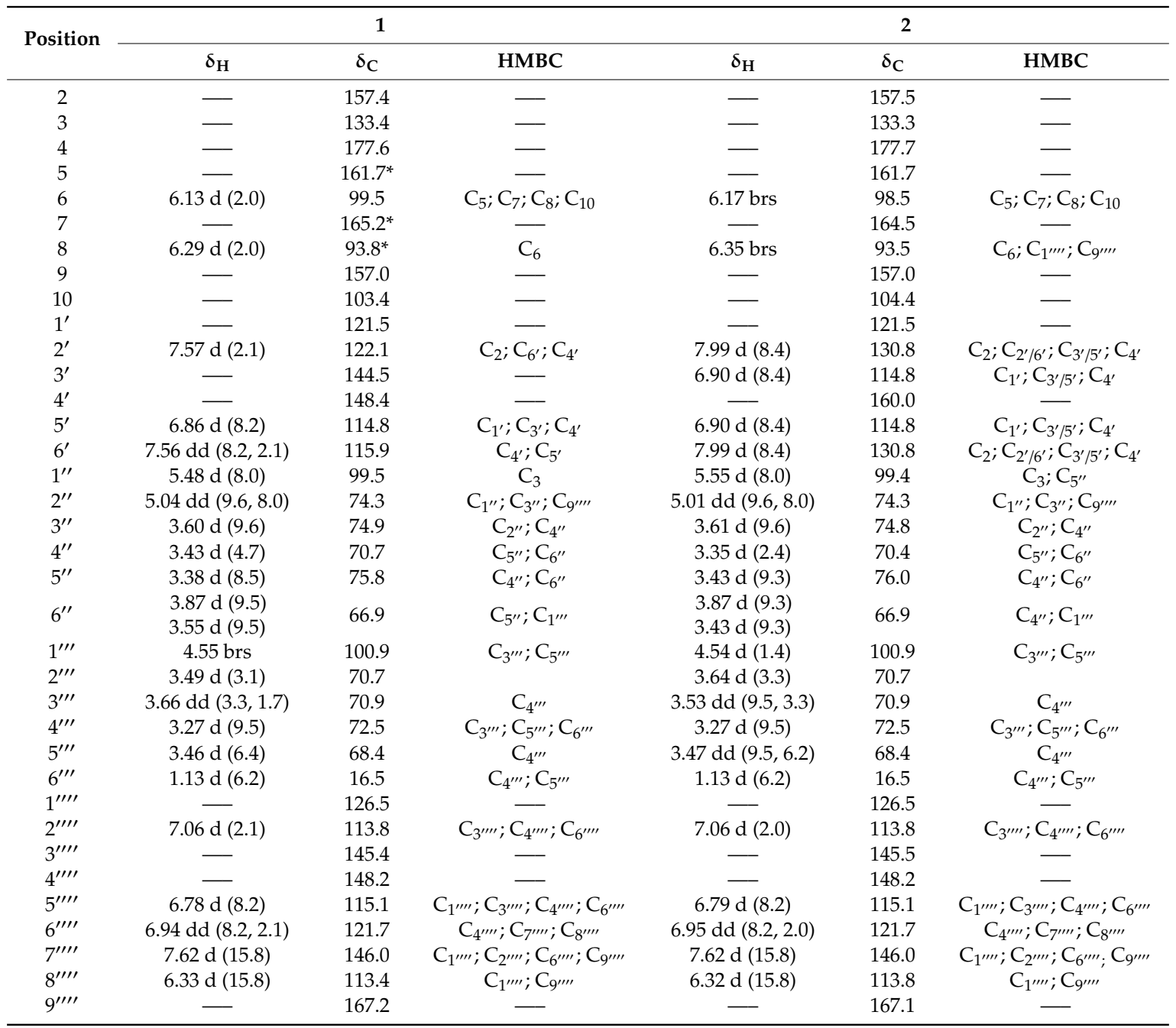

Legend: $\mathrm{d}$, doublet; $\mathrm{dd}$, doublet of doublets; brs, broad singlet; *, chemical shift obtained from HSQC and HMBC spectra.

Similarly to structure 1 , the ${ }^{1} \mathrm{H}$ NMR spectrum showed two other doublets at $7.62(1 \mathrm{H}, J=15.8 \mathrm{~Hz}$, $\left.\mathrm{H}-7^{\prime \prime \prime \prime}\right)$ and $\delta 6.32\left(1 \mathrm{H}, J=15.8 \mathrm{~Hz}, \mathrm{H}-8^{\prime \prime \prime \prime}\right)$ assigned to trans-hydrogens from an $\alpha, \beta$-unsaturated carboxyl group, two doublets at $\delta 7.06\left(1 \mathrm{H}, J=2.0 \mathrm{~Hz}, \mathrm{H}-2^{\prime \prime \prime \prime}\right)$ and $\delta 6.79\left(1 \mathrm{H}, J=8.2 \mathrm{~Hz}, \mathrm{H}-5^{\prime \prime \prime \prime}\right)$, and a doublet of doublets at $\delta 6.95\left(1 \mathrm{H}, J=2.0 \mathrm{~Hz}\right.$ and $\left.8.2 \mathrm{~Hz}, \mathrm{H}-6^{\prime \prime \prime \prime}\right)$ assigned to the presence of a caffeoyl group in the structure. Additionally, the spectrum showed two doublets at $\delta 5.55\left(1 \mathrm{H}, J=8.0 \mathrm{~Hz}, \mathrm{H}-1^{\prime \prime}\right)$ and $\delta 4.54\left(1 \mathrm{H}, J=1.4 \mathrm{~Hz}, \mathrm{H}-1^{\prime \prime \prime}\right)$, which is typical of hydrogens bonded in anomeric carbons. Three additional doublets at $3.87\left(1 \mathrm{H}, J=9.3 \mathrm{~Hz}, \mathrm{H}-6^{\prime \prime}\right), \delta 3.43\left(1 \mathrm{H}, J=9.3 \mathrm{~Hz}, \mathrm{H}-6^{\prime \prime}\right)$ and $\delta 1.13(3 \mathrm{H}, J=6.2 \mathrm{~Hz}$, $\left.\mathrm{H}-6^{\prime \prime \prime}\right)$ suggested the presence of a glycosyl moiety substituted at C- $6^{\prime \prime}$ and a rhamnosyl unit in the structure. The doublet of doublets at $\delta 5.01\left(1 \mathrm{H}, J=8.0 \mathrm{~Hz}\right.$ and $\left.9.6 \mathrm{~Hz}, \mathrm{H}-2^{\prime \prime}\right)$ suggested the presence of a substituent group at C-2" from a glycosyl moiety.

The ${ }^{13} \mathrm{C}-\mathrm{NMR}$ spectrum displayed thirty-four carbon signals, including a carbonyl, a carboxyl, twelve quaternary carbons, eight unsaturated methines, ten oxymethines, one oxygenated methylene, and one methyl group. Through HMBC correlations, it was possible to establish the connectivity among groups in the structure. The signals at $\delta 5.55$ and $\delta 5.01$ attributed to $\mathrm{H}-1^{\prime \prime}$ and $\mathrm{H}-2^{\prime \prime}$ of the glycosyl moiety correlated with the carbons at $\delta 133.3$ and $\delta 167.1$, respectively, which were attributed 
to C-3 from kaempferol and to C-9'"' from a caffeoyl group, confirming the bond of glucose at C-3 of kaempferol and the caffeoyl group esterified on hydroxyl at C-2" of glucose. Other key HMBC correlations are shown in Figure 2 and other signals of compound 2 were assigned and are shown in Table 1.

The known compounds were identified as caffeic acid (3) [27], chlorogenic acid (5-O-(E)caffeoylquinic acid (4)) [28], rutin (quercetin-3-O-rutinoside (5)) [29], nicotiflorin (kaempferol-3-Orutinoside (6)) [30], 4,5-di-O-(E)-caffeoylquinic acid (7) [31], 3,5-di-O-(E)-caffeoylquinic acid (8) [31], 3,4-di-O-(E)-caffeoylquinic acid (9) [31], and 3,4,5-tri-O-(E)-caffeoylquinic acid (10) [28] by analyzing their spectral data and comparing them with reported literature values.

Flavonoids and chlorogenic acid derivatives are components known for their antiradical activity [30]. Thus, the isolated compounds (1-10) were tested for their antiradical activity using a DPPH assay. Compounds $\mathbf{1}$ and $\mathbf{2}$ exhibited a high activity compared to Trolox (Table 2). These components had higher antiradical activity than their respective non-acylated flavonoids. All chlorogenic acids were more active than Trolox as observed previously in the literature [31]. Additionally, the chlorogenic acid derivatives substituted by caffeoyl groups at the C-4 position showed antiradical activity compatible with the new acylated flavonoids.

Table 2. Antiradical activity of compounds 1-2.

\begin{tabular}{cccc}
\hline Compound & \% Trolox $\left(\mathbf{L} \cdot \boldsymbol{\mu} \mathbf{m o l}^{-\mathbf{1}}\right)$ & $\mathbf{I C}_{\mathbf{5 0}}\left(\boldsymbol{\mu \mathbf { m o l } \cdot \mathbf { L } ^ { - \mathbf { 1 } } )}\right.$ & $\mathbf{n}$ \\
\hline (1) Oblongifolioside A & $245.5 \pm 0.1$ & $13.3 \pm 0.5$ & $4.8 \pm 0.1$ \\
(2) Oblongifolioside B & $244.9 \pm 0.2$ & $12.4 \pm 0.2$ & $4.8 \pm 0.2$ \\
Trolox & - & $45.4 \pm 1.7$ & $1.96 \pm 0.06$ \\
\hline
\end{tabular}

Legend: $\mathrm{n} *$, number of radicals trapped by molecule of antiradical.

\section{Materials and Methods}

\subsection{General Experimental Procedures}

Column chromatography (CC) was performed on a Sephadex LH-20 (GE Healthcare). HPLC grade solvents of the trademark T.J. Baker were used for the HPLC chromatography analyses. Analytical HPLC analyses were carried out on an Agilent 1260 system (G1311 pump 110 and G1315D photodiode array detector; Palo Alto, US) with a $60 \mathrm{~mm}$ flow cell. Zorbax Eclipse plus reverse phase C18 (4.6 mm $\times 150 \mathrm{~mm}, 3.5 \mu \mathrm{m}$, Agilent) was used as the stationary phase and a flow rate of $1.0 \mathrm{~mL} \cdot \mathrm{min}^{-1}$ was employed for analyses on the analytical scale. For separation of compounds the Agilent 1200 semi-preparative chromatograph system (Palo Alto, US) was used with a C18 Zorbax eclipse plus LC-18 column $(25 \mathrm{~cm} \times 10 \mathrm{~mm})$ with $5 \mu \mathrm{m}$ diameter particles and a flow rate of $4.176 \mathrm{~mL} \cdot \mathrm{min}^{-1}$ of solvent A: milli-Q water acidified with $0.1 \%$ acetic acid $(v / v)$ and solvent B: acetonitrile (ACN). The column temperature was $45^{\circ} \mathrm{C}$, the injection volume of the sample was $200 \mu \mathrm{L}$ and the sample was dissolved in methanol at a concentration of $100 \mathrm{~g} \cdot \mathrm{L}^{-1}$. NMR spectra of hydrogen-1 $\left({ }^{1} \mathrm{H}-\mathrm{NMR}\right)$ and carbon-13 $\left({ }^{13} \mathrm{C}-\mathrm{NMR}\right)$ were recorded on a Bruker AIII $500 \mathrm{MHz}$ spectrometer (MA, US) operating at $500 \mathrm{MHz}$ for ${ }^{1} \mathrm{H}-\mathrm{NMR}$ and $125 \mathrm{MHz}$ for ${ }^{13} \mathrm{C}-\mathrm{NMR}$ at the Institute of Chemistry of the University of São Paulo. The spectra were obtained in deuterated methanol from Sigma-Aldrich as a solvent. NMR data were processed using MestreNova 9.0 software. Optical rotations were measured on a Perkin Elmer 243B polarimeter. Mass spectra were recorded on an Amazon ETD Bruker Daltonics (MA, US) with capillary $4500 \mathrm{~V}$ and nebulizer at 27 psi in a negative mode.

\subsection{Plant Material}

Leaves of Baccharis oblongifolia (Ruiz and Pav.) Pers. (Asteraceae) were collected from Campos do Jordão, São Paulo, Brazil on October 22, 2016 (-22 $45^{\prime} 47^{\prime \prime}$ S; $\left.-45^{\circ} 35^{\prime} 02^{\prime \prime} \mathrm{W}\right)$. The plant was identified 
by Professor Dr. Oriana A. Fávero and a voucher specimen (Fávero et al. 535) was deposited at the Herbarium of the University of São Paulo (SPF).

\subsection{Extraction and Isolation}

Dried leaves of B. oblongifolia (373 g) were powdered and extracted with hexane and subsequently with ethanol $(\mathrm{EtOH})$. EtOH extract $(79.8 \mathrm{~g})$ was resuspended in EtOH: $\mathrm{H}_{2} \mathrm{O}(1: 1)$ and partitioned successively with hexanes, dichloromethane (DCM), and ethyl acetate (EtOAc).

The EtOAc phase ( $4.5 \mathrm{~g}$ ) was subjected to Sephadex LH-20 column chromatography and eluted with methanol to afford seven groups (Gr. A-G). Gr. B and C were subjected to separation by semi-preparative HPLC (0-3 min: $10 \rightarrow 20 \% \mathrm{ACN}$; 3-7 min: 20\% ACN) to afford, respectively, caffeic acid (3, $45.3 \mathrm{mg})$ and chlorogenic acid (4,90.5 mg). Gr. D was subjected to semi-preparative HPLC (0-3 min: $10 \rightarrow 20 \%$ ACN; 3-7 min: 20\% ACN; 7-8 min: $20 \rightarrow 25 \%$ ACN; 8-12 min: $25 \%$ ACN) to give rutin $(5,22.4 \mathrm{mg}$, quercetin-3-O-rutinoside) and nicotiflorin $(6,11.5 \mathrm{mg}$, kaempferol-3-Orutinoside). Gr. E was subjected to semi-preparative HPLC (0-3 min: $10 \rightarrow 20 \%$ ACN; 3-7 min: 20\% ACN; 7-8 min: $20 \rightarrow 25 \%$ ACN; 8-12 min: 25\% ACN; 12-17 min: $25 \rightarrow 50 \%$ ACN; 17-22 min: $50 \rightarrow 100 \%$ ACN; $22-22.5 \mathrm{~min}: 100 \% \mathrm{ACN})$ to yield 4,5-di-O-(E)-caffeoylquinic acid $(7,77.3 \mathrm{mg})$, 3,5-di-O-(E)-caffeoylquinic acid (8, $235.9 \mathrm{mg})$, and 3,4-di-O-(E)-caffeoylquinic acid (9, $95.5 \mathrm{mg})$. The same elution conditions for Gr. E were used to subject Gr. F and G to semi-preparative HPLC. Gr. F afforded oblongifolioside A (1, $27.8 \mathrm{mg}$, quercetin-3-O- $\beta-\left[2^{\prime \prime}-O-(E)\right.$-caffeoyl]-rutinoside) and oblongifolioside B (2, $16.8 \mathrm{mg}$, kaempferol-3-O- $\beta-\left[2^{\prime \prime}-O-(E)\right.$-caffeoyl]-rutinoside) while Gr. G yielded 3,4,5-tri-O-(E)caffeoylquinic acid $(\mathbf{1 0}, 5.0 \mathrm{mg})$.

Oblongifolioside A (1): yellow powder; $[\alpha]^{25} \mathrm{D}+11.7^{\circ}$ (c $\left.0.01, \mathrm{MeOH}\right) .{ }^{1} \mathrm{H}$ and ${ }^{13} \mathrm{C}-\mathrm{NMR}$ spectral data, see Table 1; HR-ESI-MS: $m / z$ [M - H] $]^{-}$, calcd. for $\mathrm{C}_{36} \mathrm{H}_{35} \mathrm{O}_{19}$ : 771.1772, found: 771.1711.

Oblongifolioside B (2): yellow powder; $[\alpha]^{25} \mathrm{D}+13.4^{\circ}$ (c $\left.0.01, \mathrm{MeOH}\right) .{ }^{1} \mathrm{H}$ and ${ }^{13} \mathrm{C}-\mathrm{NMR}$ spectral data, see Table 1; HR-ESI-MS: $m / z$ [M - H] $]^{-}$, calcd. for $\mathrm{C}_{36} \mathrm{H}_{35} \mathrm{O}_{18}$ : 755.1823, found: 755.1881.

\subsection{Antiradical Assay}

Evaluation of antiradical activity was performed according to a protocol published in the literature [32]. Briefly, the DPPH solution was prepared from $3.5 \mathrm{mg}$ to $3.9 \mathrm{mg}$ of DPPH in $50 \mathrm{~mL}$ of methanol. The exact concentration of the DPPH solution was determined spectrophotometrically by the maximum absorbance at $515 \mathrm{~nm}\left(\varepsilon_{\mathrm{DPPH}}=1.25 \times 10^{4} \mathrm{~L} \cdot \mathrm{mol}^{-1} \cdot \mathrm{cm}^{-1}\right)$. The Trolox antiradical solution was prepared with $1.25 \mathrm{mg}$ in $2.5 \mathrm{~mL}$ methanol. The solutions prepared remained for $5 \mathrm{~min}$ in a sonicator for complete solubilization.

Analyses were performed on a microplate reader for absorbance with an optical path of $5 \mathrm{~mm}$ with a total volume of $220 \mu \mathrm{L}$. Measurements were initiated by the addition of $200 \mu \mathrm{L}$ DPPH in $20 \mu \mathrm{L}$ of the sample solution (pure compound). The kinetics of the reactions were observed by absorbance of the DPPH solution at $515 \mathrm{~nm}$. All kinetic tests were performed in triplicate in independent measurements and the results treated and represented with mean \pm standard deviation in the program Origin Pro 8.5 to obtain the kinetic curves.

The variation of absorbance ( $\triangle \mathrm{Abs}$.) between T0 and T50 (AbsTinitial-AbsTfinal) shows a linear correlation with the antiradical concentration. In order to calculate the antiradical activity of the phases and pure compounds, the angular coefficients $(\alpha)$ of the antiradical (A) and Trolox (T) standard deviations were used as a function of the absorbance variation in order to obtain the corresponding antiradical capacity as a percentage of Trolox (\%Tx), according to Equation (1) [32]:

$$
\% \mathrm{Tx}=(\alpha \mathrm{A} / \alpha \mathrm{T}) \times 100
$$

In addition to correlating the concentration of the antiradical compound with the variation of the absorbance, the correlation of this concentration was also made directly with the concentration of the 
DPPH radical consumed. From this correlation it was possible to directly obtain the number of DPPH radicals sequestered per antiradical molecule.

The percentage of antiradical activity was calculated from Equation (2), where the negative control was prepared with $200 \mu \mathrm{L}$ of DPPH and $20 \mu \mathrm{L}$ of methanol, the blank was prepared with $20 \mu \mathrm{L}$ of the sample and $200 \mu \mathrm{L}$ of methanol, and the sample was prepared with $20 \mu \mathrm{L}$ of the sample and $200 \mu \mathrm{L}$ of $\mathrm{DPPH}$. The $50 \%$ inhibitory concentration $\left(\mathrm{IC}_{50}\right)$ of each compound was obtained from the equation of the straight line of the concentration graph by the percentage of antiradical activity.

$$
\mathrm{AA} \%=100-\left\{\left[\left(\mathrm{ABS}_{\mathrm{SAMPLE}}-\mathrm{ABS}_{\mathrm{BLANK}}\right) \times 100\right] / \mathrm{ABS}_{\text {NEGATIVE }}\right\}
$$

Supplementary Materials: The following are available online. Figures S1-S11: Spectral data of compounds 1 and 2.

Author Contributions: P.R., O.A.F., and M.J.P.F. collected the plant. P.R.F.Z. developed the extraction and chromatographic procedures to isolate the compounds. P.R.F.Z. and C.I.T. conducted the antiradical assays. C.I.T. and M.J.P.F. were responsible for the structural elucidation of the compounds. P.R.F.Z., C.I.T., and M.J.P.F. wrote the original draft. All authors were involved in the analysis of the data and reviewed and wrote the final version of the manuscript. M.J.P.F designed and supervised the project and was responsible for funding acquisition.

Funding: This research was funded by FAPESP (2014/21593-2, Brazil) and CAPES (Finance Code 001, Brazil). M.J.P.F. was funded by a fellowship from CNPq.

Acknowledgments: The authors thank the technical support provided by Phytochemistry Lab at IB-USP.

Conflicts of Interest: The authors declare no conflict of interest.

\section{References}

1. Müller, J. Systematics of Baccharis (Compositae-Astereae) in Bolivia, including an overview of the genus. Syst. Bot. Monographs 2006, 76, 1-341.

2. Heiden, G.; Pirani, J.R. Novelties towards a phylogenetic infrageneric classification of Baccharis (Asteraceae, Astereae). Phytotaxa 2016, 289, 285-290. [CrossRef]

3. Heiden, G.; Schneider, A. Baccharis in Lista de Espécies da Flora do Brasil. Jardim Botânico do Rio de Janeiro. 2015. Available online: http://floradobrasil.jbrj.gov.br/jabot/floradobrasil/FB5151 (accessed on 5 August 2019).

4. Verdi, L.G.; Brighente, I.M.C.; Pizzolatti, M.G. Gênero Baccharis (Asteraceae): Aspectos químicos, econômicos e biológicos. Quim. Nova 2005, 28, 85-94. [CrossRef]

5. Campos, F.R.; Bressan, J.; Jasinski, V.C.G.; Zuccolotto, T.; Silva, L.E.; Cerqueira, L.B. Baccharis (Asteraceae): Chemical constituents and biological activities. Chem. Biodivers. 2016, 13, 1-17. [CrossRef] [PubMed]

6. Abad, M.J.; Bermejo, P. Baccharis (Compositae): A review update. Arkivoc 2007, 7, 76-96. [CrossRef]

7. Simões-Pires, C.A.; Queiroz, E.F.; Henriques, A.T.; Hostettmann, K. Isolation and on-line identification of antioxidant compounds from three Baccharis species by HPLC-UV-MS/MS with post-column derivatisation. Phytochem. Anal. 2005, 16, 307-314. [CrossRef] [PubMed]

8. Grecco, S.S.; Ferreira, M.J.P.; Romoff, P.; Fávero, O.A.; Lago, J.H.G. Phenolic derivatives from Baccharis retusa DC. (Asteraceae). Biochem. Syst. Ecol. 2012, 42, 21-24. [CrossRef]

9. Grecco, S.S.; Félix, M.J.P.; Lago, J.H.G.; Pinto, E.G.; Tempone, A.G.; Ferreira, M.J.P.; Romoff, P.; Sartorelli, P. Anti-trypanosomal phenolic derivatives from Baccharis uncinella C. DC. (Asteraceae). Nat. Prod. Commun. 2014, 9, 171-173. [CrossRef]

10. Toyama, D.O.; Ferreira, M.J.P.; Romoff, P.; Fávero, O.A.; Gaeta, H.H.; Toyama, M.H. Effect of chlorogenic acid (5-caffeoylquinic acid) isolated from Baccharis oxyodonta on the structure and pharmacological activities of secretory phospholipase A2 from Crotalus durissus terrificus. BioMed Res. Int. 2014, article ID 726585. [CrossRef]

11. Sayuri, V.A.; Romoff, P.; Fávero, O.A.; Ferreira, M.J.P.; Lago, J.H.G.; Buturi, F.O.S. Chemical composition, seasonal variation and biosynthetic considerations of essential oils from Baccharis microdonta and B. elaeagnoides (Asteraceae). Chem. Biodivers. 2010, 7, 2771-2782. [CrossRef] 
12. Budel, J.M.; Wang, M.; Raman, V.; Zhao, J.; Khan, S.I.; Rehman, J.U.; Techen, N.; Tekwani, B.; Monteiro, L.M.; Heiden, G.; et al. Essential oils of five Baccharis species: investigations on the chemical composition and biological activities. Molecules 2018, 23, 2620. [CrossRef] [PubMed]

13. Ascari, J.; Oliveira, M.S.; Nunes, D.S.; Granato, D.; Scharf, D.R.; Simionatto, E.; Otuki, M.; Soley, B.; Heiden, G. Chemical composition, antioxidant and anti-inflammatory activities of the essential oils from male and female specimens of Baccharis punctulata (Asteraceae). J. Ethnopharmacol. 2019, 234, 1-7. [CrossRef] [PubMed]

14. Zuccolotto, T.; Bressan, J.; Lourenco, A.V.F.; Bruginski, E.; Veiga, A.; Marinho, J.V.N.; Raeski, P.A.; Heiden, G.; Salvador, M.J.; Murakami, F.S.; et al. Chemical, antioxidant, and antimicrobial evaluation of essential oils and an anatomical study of the aerial parts from Baccharis species (Asteraceae). Chem. Biodivers. 2019, 16, e1800547. [CrossRef]

15. Sobrinho, A.C.N.; Souza, E.B.; Rocha, M.F.G.; Albuquerque, M.R.J.R.; Bandeira, P.N.; Santos, H.S.; Cavalcante, C.S.P.; Oliveira, S.S.; Aragão, P.R.; Morais, S.M.; et al. Chemical composition, antioxidant, antifungal and hemolytic activities of essential oil from Baccharis trinervis (Lam.) Pers. (Asteraceae). Ind. Crops Prod. 2016, 84, 108-115. [CrossRef]

16. Grecco, S.S.; Gimenes, L.; Ferreira, M.J.P.; Romoff, P.; Fávero, O.A.; Zalewski, C.A.; Lago, J.H.G. Triterpenoids and phenolic derivatives from Baccharis uncinella C.DC. (Asteraceae). Biochem. Syst. Ecol. 2010, 38, 1234-1237. [CrossRef]

17. Alvarenga, S.A.V.; Ferreira, M.J.P.; Rodrigues, G.V.; Emerenciano, V.P. A general survey and some taxonomic implications of diterpenes in the Asteraceae. Bot. J. Linn. Soc. 2005, 147, 291-308. [CrossRef]

18. Seaman, F.; Bohlmann, F.; Zdero, C.; Mabry, T.J. Diterpenes of flowering plants - Compositae (Asteraceae); Springer: New York, NY, USA, 1990.

19. Funes, M.; Garro, M.F.; Tosso, R.D.; Maria, A.O.; Saad, J.R.; Enriz, R.D. Antinociceptive effect of neo-clerodane diterpenes obtained from Baccharis flabellata. Fitoterapia 2018, 130, 94-99. [CrossRef]

20. Moreira, C.P.S.; Oliveira, D.M.; Santos, C.N.; Zani, C.L.; Alves, T.M.A. Platypodiol a novel clerodane diterpene from Baccharis platypoda. Tetrah. Lett. 2014, 55, 4898-4900. [CrossRef]

21. Ueno, A.K.; Barcellos, A.F.; Grecco, S.S.; Sartorelli, P.; Guadagnin, R.C.; Romoff, P.; Ferreira, M.J.P.; Tcacenco, C.M.; Lago, J.H.G. Sesquiterpenes, diterpenes, alkenyl p-coumarates and flavonoid from the aerial parts of Baccharis retusa (Asteraceae). Biochem. Syst. Ecol. 2018, 78, 39-42. [CrossRef]

22. Simirgiotis, M.J.; Quispe, C.; Bórquez, J.; Mocan, A.; Sepúlveda, B. High resolution metabolite fingerprinting of the resin of Baccharis tola Phil. from the Atacama Desert and its antioxidant capacities. Ind. Crops Prod. 2016, 94, 368-375. [CrossRef]

23. Gomez, J.; Simirgiotis, M.J.; Lima, B.; Paredes, J.D.; Gabutti, C.M.V.; Gamarra-Luques, C.; Borquez, J.; Luna, L.; Wendel, G.H.; Maria, A.O.; et al. Antioxidant, gastroprotective, cytotoxic activities and UHPLC PDA-Q orbitrap mass spectrometry identification of metabolites in Baccharis grisebachii decoction. Molecules 2019, 24, 1085. [CrossRef] [PubMed]

24. Grecco, S.S.; Reimão, J.Q.; Tempone, A.G.; Sartorelli, P.; Romoff, P.; Ferreira, M.J.P.; Fávero, O.A.; Lago, J.H.G. Isolation of an antileishmanial and antitrypanosomal flavanone from the leaves of Baccharis retusa (Asteraceae). Parasitol. Res. 2010, 106, 1245-1248. [CrossRef] [PubMed]

25. Grecco, S.S.; Reimão, J.Q.; Tempone, A.G.; Sartorelli, P.; Cunha, R.L.O.R.; Ferreira, M.J.P.; Romoff, P.; Fávero, O.A.; Lago, J.H.G. In vitro antileishmanial and antitrypanosomal activities of flavanones from Baccharis retusa DC. (Asteraceae). Exp. Parasitol. 2012, 130, 141-145. [CrossRef] [PubMed]

26. Bohm, B.A.; Stuessy, T.F. Flavonoids of the Sunflower Family; SpringerWien: New York, NY, USA, 2001.

27. Sari, A.; Keçeci, Z. Phytochemical investigation on chemical constituents of Taraxacum bessarabicum (Hornem.) Hand.-Mazz. subsp. bessarabicum (Hornem.) Hand.-Mazz. Iranian J. Pharm. Res. 2019, 18, 400-405.

28. Tamayose, C.I.; Torres, P.B.; Roque, N.; Ferreira, M.J.P. HIV-1 reverse transcriptase inhibitory activity of flavones and chlorogenic acid derivatives from Moquiniastrum floribundum (Asteraceae). South Afr. J. Bot. 2019, 123, 142-146. [CrossRef]

29. Beck, M.-A.; Häberlein, H. Flavonol glycosides from Elchscholtzia californica. Phytochemistry 1999, 50, 329-332. [CrossRef]

30. Sang, S.; Lapsley, K.; Jeong, W.-S.; Lachance, P.A.; Ho, C.-T.; Rosen, R.T. Antioxidative phenolic compounds isolated from almond skins (Prunus amygdalus Batch). J. Agric. Food Chem. 2002, 50, 2459-2463. [CrossRef] [PubMed] 
31. Tamayose, C.I.; Santos, E.A.; Roque, N.; Costa-Lotufo, L.V.; Ferreira, M.J.P. Caffeoylquinic acids: Separation method, antiradical properties and cytotoxicity. Chem. Biodivers. 2019, 16, e1900093. [CrossRef]

32. Oliveira, S.; Souza, G.A.; Eckert, C.R.; Silva, T.A.; Sobral, E.S.; Fávero, O.A.; Ferreira, M.J.P.; Romoff, P.; Baader, W.J. Evaluation of antiradical assays used in determining the antioxidant capacity of pure compounds and plant extracts. Quim. Nova 2014, 37, 497-503. [CrossRef]

Sample Availability: Samples of the compounds 1-10 are available from the authors.

(C) 2019 by the authors. Licensee MDPI, Basel, Switzerland. This article is an open access article distributed under the terms and conditions of the Creative Commons Attribution (CC BY) license (http://creativecommons.org/licenses/by/4.0/). 